\title{
Changes in chemical and microbiological composition of two varieties of olive during fermentation
}

\author{
By M. Borcakli (1), G. Özay (1), I. Alperden (1), E. Özsan (2) and Y. Erdek (2) \\ 1. TÜBITAK, Marmara Research Center, Department of Food and Refrigeration Technology. PO.Box 21. 41470. Gebze, KOCAELI-TÜRKIYE \\ 2. MARMARABIRLIK (Union of the Olive Producers Cooperatives) Inönü Caddesi Inegöl Çarsisi. Kat:4. BURSA-TÜRKIYE.
}

\section{RESUMEN}

Cambios en la composición química y microbiológica de dos variedades de aceituna durante la fermentación.

En este estudio, se han examinado los cambios en la composición química y microbiológica de dos variedades de aceituna, Edincik y Gemlik, durante la fermentación a escala industrial.

Las aceitunas se caracterizaron química y microbiológicamente antes del tratamiento. Posteriormente, la naturaleza del proceso se investigó durante los nueve meses del periodo de fermentación tomando muestras cada ciertos intervalos. Se determinaron las características más importantes de las dos variedades antes del tratamiento: la variedad Edincik tuvo un mayor contenido relativo en azúcares reductores (5.94\%) y humedad (59.53\%) que la variedad Gemlik (4.45\% azúcares reductores y $43,18 \%$ humedad). Las concentraciones de polifenoles de las dos variedades fueron $2.50 \%$ y $2.40 \%$ respectivamente. Durante la fermentación, los contenidos en azúcares reductores y polifenoles disminuyeron gradualmente en el fruto, mientras que otros constituyentes cambiaron ligeramente o permanecieron casi inalterados. En la salmuera los azúcares reductores disminuyeron hasta valores de $0.98 \%$ y $0.65 \%$, aumentando la acidez libre hasta $0.41 \%$ y $0.35 \%$, con unos valores de $\mathrm{pH}$ de 4.4 y 4.9 , alcanzando el contenido en sal en el fruto valores finales de $7.4 \%$ y $6.9 \%$ para las variedades Edincik y Gemlik respectivamente. La microflora de las muestras originales estuvo constituida por bacterias, principalmente del tipo: lactobacilos, Gram-negativo, anaerobios productores de sulfuro, bacterias coliformes y hongos. Durante la fermentación de ambas variedades, los hongos fueron controlados a los 40 días de fermentación.

PALABRAS-CLAVE: Aceituna - Composición microbiológica - Composición química - Fermentación.

\section{SUMMARY}

Changes in chemical and microbiological composition of two varieties of olive during fermentation.

In this study, the changes in chemical and microbiological composition of two olive varieties, Edincik and Gemlik, have been examined during fermentation at industrial scale.

Prior to processing, the olives have been thoroughly characterized chemically and microbiologically. Then, the nature of the fermentation process has been investigated during the 9 months of fermentation period by taking samples at certain intervals. The most important characteristics of the two varieties before processing were determined as follows: Edincik variety was found to have relatively higher reducing sugar $(5.94 \%)$ and moisture $(59.53 \%)$ contents than that Gemlik variety $(4.45 \%$ reducing sugar and $43.18 \%$ moisture). Polyphenol concentrations of two varieties were $2.50 \%$ and $2.40 \%$, respectively. During fermentation, reducing sugar and polyphenols contents were decreased gradually in the fruit, while other constituents were slightly changed or remained almost unchanged. While reducing sugar decreased to the values of $0.98 \%$ and $0.65 \%$, free acidity in brine increased to $0.41 \%$ and $0.35 \%, \mathrm{pH}$ value of brine were 4.4 and 4.9 and salt content in fruit were reached to the final values of $7.4 \%$ and $6.9 \%$ for Edincik and Gemlik varieties, respectively. Microflora of the raw samples was consisted of various bacteria mainly, lactobacilli, Gram-negative, anaerobic sulfide producing, coliform bacteria and yeasts. During the fermentation of both varieties, yeasts were dominated starting from the 40th days of fermentation.

KEY-WORDS: Chemical composition - Fermentation - Microbiological composition - Olive.

\section{INTRODUCTION}

Olive is one of the major agricultural products of Turkey and Turkey has the second place among olive cultivating countries in the world (1). The most common two Turkish olive varieties, namely Gemlik and Edincik, constitutes the major part of the olive production in the region of the Sea of Marmara (North-West of Turkey), and are best suited for processing natural black olives. Gemlik variety, with an average size of $270-280$ olives $/ \mathrm{kg}$ has a high oil content. Edincik variety, with an average size of $230-400$ olives $/ \mathrm{kg}$ is characterised by firm flesh, comparably low oil, high moisture and sugar contents.

For processing the black olives in Turkey, olives are harvested when fully ripe, and after sorting are put into concrete basins containing brine of $12-14 \% \mathrm{NaCl}$. Fermentation, through action of microorganisms, takes place until undesirable bitterness is reduced. When the fermentation finishs, the olives are packed in tin containers with the capacities of $1-10 \mathrm{~kg}$, using freshly prepared brine of 11 $12 \% \mathrm{NaCl}$. This is the most common process in Turkey and the process is based upon traditional practices. The fer'mentation process is very slow (almost 9-10 months' period) because the diffusion of soluble components into the brine is difficult since the fruit is not subjected to any pretreatment. The final product is usually shrivelled, has slightly soft flesh and characteristic aroma is masked by salty taste. Recently, intensive researches have been conducted on olive fermentation in Turkey to produce high quality table olives.

The main objective of this study is examining the nature of fermentation and the availability of the two common 
varieties for processing, and furthermore, determining the required modifications in olive processing technology to obtain high quality final products.

\section{MATERIAL AND METHODS}

\subsection{Material}

Ripe olives of Gemlik and Edincik varieties, with an average size of 299 and $430 \mathrm{fruit} / \mathrm{kg}$, respectively, from the 1990 crop were fermented at industrial scale (a plant of MARMARABIRLIK, Union of Olive Producers Cooperatives) in concrete basins. Representative samples of brine and olive were taken from each basin during fermentation under factory conditions. Sampling was made every 15 days of the initial phase, and then at 30 days intervals during the subsequent period. The samples were brought to MRC laboratories in plastic jars and in sterile polyethylene bags for microbiological analyses. They were stored in refrigerator $\left(4^{\circ} \mathrm{C}\right)$ until analysis.

\subsection{Technological method}

The traditional pickling process was about as follows: The fully ripe olives were sorted and placed in concrete basins with capacity of 10 metric tonnes $(2 \times 2 \times 2.5 \mathrm{~m})$ containing brine of $14 \% \mathrm{NaCl}$. The ratio of olive to brine was 4 to 1 . Then the basins were covered with wooden planks and slighly pressed to keep the fruits in the brine. The brine was circulated once in a month and there was no salt addition during the fermentation.

\subsection{Methods of analyses}

a) Isolation and identification of the microorganisms

Enumeration of microorganisms were carried out on solidified media after preparing homogenized dilutions of $20 \mathrm{~g}$ olive or $20 \mathrm{ml}$ brine samples. Appropriate dilutions were plated on Rogosa Agar (2) and Modified Chalmer's Agar (3) for the lactic acid bacteria, Plate Count Agar plus penicillin (2) for Gram-negative bacteria, Modified Clostridium Medium for anaerobic, sulfide producing bacteria, Baird-Parker Agar for staphylococci and Oxytetracycline Glucose Yeast Agar (4) for yeasts. The most Probable Number Method (5) was used for the enumeration of the coliform bacteria.
Yeast strains were conserved on Yeast Malt Agar slants and the identification were performed according to the morphological and physiological methods (6). Results of the tests were assessed according to the yeast identification manuals and relevant PC Programme (7).

b) Chemical Analyses

Titratable acidity and salt content of olive and brine samples were determined by titrimetric methods of IOOC (8). Reducing sugar analyses were carried out according to the Layne-Eynon method (9). Spectrophotometric measurement of polyphenols, analyses of moisture, fat and ash contents were realized according to the methods of Fernandez Diez et al., (10). Protein content (Nx6.25) of the fruit was determined by Kjeltech apparatus (Tecator). $\mathrm{pH}$ values were measured using $\mathrm{pH}$ meter (Metrohm).

\section{RESULTS AND DISCUSSION}

\subsection{Composition of raw olives}

The principle characteristics of the olive fruit to be considered during fermentation are the type and the quantity of microorganisms, reducing sugar, moisture and polyphenol contents. The chemical composition of the fruit depends on several factors such as variety, the state of maturity at the time of harvest. To a lesser degree variations in these characteristics depend on the geographical area, the quality of the soil, and the type of cultivation on irrigated or nonirrigated but arable land (11). Considering all these facts, raw olives of the two varieties were submitted to microbiological and chemical analyses before being placed in brine. According to the results of chemical analyses it was observed that Edincik variety has higher reducing sugar (5.94\%) and moisture $(59.53 \%)$ content than that of Gemlik variety which is more nutritive with regard to its oil and protein content (Table I). The chemical composition of fresh fruits have been also subjected to certain investigations by other researchers and almost the comparable compositional characteristics were found (12). Gemlik olive is high in oil content and widely used for oil production in the olive industry.

The polyphenol content (as $\mathrm{g}$ tannic acid/100 ml juice) of both varieties were found to be approximately $2.4 \%$ which represents almost the same value for Lechin variety of Spanish olives (13).

Edincik variety has revealed higher quantity of reducing sugar $(5.94 \%$ juice as glucose) than Gemlik $(4.45 \%)$. Reducing sugar content of the Spanish varieties were

Table I

Chemical composition of unprocessed black olives *

\begin{tabular}{|c|c|c|c|c|c|c|c|c|}
\hline $\begin{array}{c}\begin{array}{c}\text { Variety } \\
\text { of }\end{array} \\
\text { Raw Olive }\end{array}$ & $\begin{array}{c}\text { Titratable } \\
\text { acidity } \\
\text { (\%W/W) }\end{array}$ & $\begin{array}{l}\text { Reducing } \\
\text { sugar } \\
(\% W / V)\end{array}$ & $\begin{array}{c}\text { Fat } \\
(\% W / W)\end{array}$ & $\begin{array}{l}\text { Moisture } \\
\text { (\%W/W) }\end{array}$ & $\begin{array}{c}\text { Ash } \\
(\% W / W)\end{array}$ & $\begin{array}{l}\text { Protein } \\
\text { (\%W/W) }\end{array}$ & $\begin{array}{c}\text { Polyphenol ** } \\
\text { g/100 ml. }\end{array}$ & $\begin{array}{c}\mathrm{NaCl} \\
(\% \mathrm{~W} / \mathrm{W})\end{array}$ \\
\hline GEMLIK & 0.074 & 4.45 & 22.02 & 43.18 & 1.65 & 1.67 & 2.40 & 0.054 \\
\hline EDINCIK & 0.080 & 5.94 & 20.12 & 59.53 & 1.42 & 1.16 & 2.49 & 0.043 \\
\hline
\end{tabular}

* Wet basis, flesh

** Juice basis, w/v 
Table II

Microbial composition of unprocessed black olives

\begin{tabular}{|c|c|c|c|c|c|c|}
\hline $\begin{array}{l}\text { Variety } \\
\text { of raw } \\
\text { olive } \\
\end{array}$ & $\begin{array}{l}\text { Lactobacilli } \\
\left(\text { cfu. } g^{-1}\right)\end{array}$ & $\begin{array}{l}\text { Streptococci } \\
\left(\text { cfu. } g^{-1}\right)\end{array}$ & 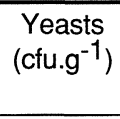 & $\begin{array}{c}\text { Gram-negative } \\
\text { bacteria } \\
\left(\text { cfu. }^{-1}\right)\end{array}$ & $\begin{array}{l}\text { Anaerobic sulfide } \\
\text { produc. bac. } \\
\text { (cfu. } \mathrm{g}^{-1} \text { ) }\end{array}$ & $\begin{array}{l}\text { Coliform } \\
\text { bacteria } \\
\left(\mathrm{cfu} . \mathrm{g}^{-1}\right)\end{array}$ \\
\hline GEMLIK & $<10$ & $<10$ & $1 \times 10^{5}$ & $3 \times 10^{5}$ & $<10$ & $<1 \times 10^{4}$ \\
\hline EDINCIK & $<10$ & $<10$ & $5 \times 10^{4}$ & $2 \times 10^{4}$ & $<10$ & $<1 \times 10^{3}$ \\
\hline
\end{tabular}

determined as $2.5,2.3,1.5 \%$ for Lechin, Hojiblanca and Verdial varieties, respectively. In this respect, the examined varieties take place among easily fermentable olives. The microbial flora of these two varieties are mainly composed of Gram-negative, coliform bacteria and yeasts. Lactic acid and anaerobic sulfide producing bacteria were not present. The absence of lactic acid bacteria and the low quantity of microbial load may be originated from excessive and unconcious use of pesiticides as well as the lack of an adequate washing procedure in olive processing (Table II). It was reported that the raw black olives usually contain a numerous and varied epiphytic microflora including many potential spoilage microorganisms and an extremely small population of lactic acid bacteria (14).

\subsection{Chemical and microbiological examination of} the fermentation

After determining the original characteristics of the raw material, studies were carried out on the investigation of the nature of fermentation, microbiologically and chemically. As is known, when olives are placed in brine, they undergo rapid physical and chemical changes. There is a vigorous withdrawal of water soluble components from olives due to the diffusion of these components into the brine, and of salt from the brine into the olive finally reaching an equilibrium after a certain period. Additionally, some of the components (i.e.sugars) are being used by microorganisms and converted to other products (acids). Consequently, these substances are reduced to a very low level as the fermentation proceeds. Furthermore, changes in chemical components are in strict relations with concomitant microbiological development during spontaneous fermentation. $\mathrm{pH}$ values and total acidity level are of primordial importance in the progress of the process. In some cases, brining can be used for temporarily storing of the fruits and vegetables when they need further processing, but in the case of the traditional olive processing method, it has a vital importance and constitutes the main treatment for the occurrence of microbial fermentation. Brining the both olive varieties involved in the establishment of yeast population rather than lactic acid bacteria which is not resistant to high concentrations of salt. The salt concentration is an important factor in governing the diffusion of soluble constituents as well as the microbial growth, and therefore the rate of the fermentation (10). In our study, after brining olives, the salt concentration in brine were reached at an equilibrium between the 75th and the 100th days of the fermentation for Edincik variety and after the 100 days for Gemlik variety (Figure 1). The final equili- brium concentrations in brine were $11.3 \%$ for Edincik and $12 \%$ for Gemlik olives.

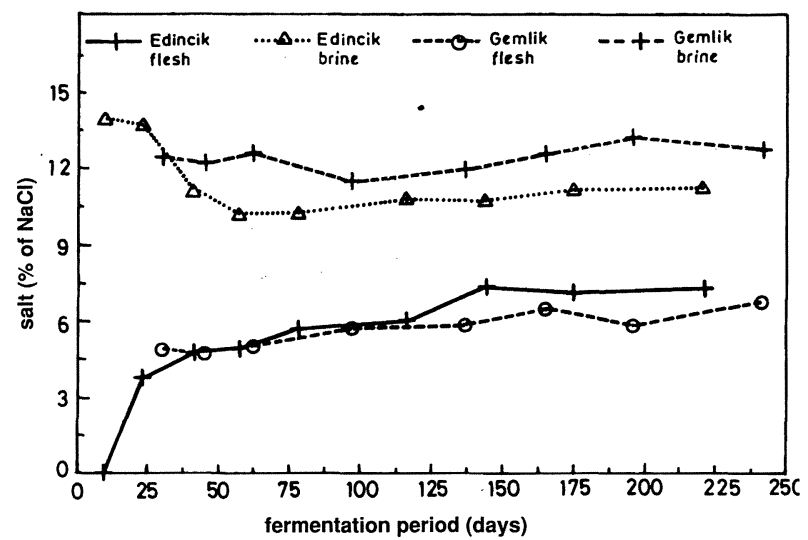

Fig. 1

Changes in the salt concentration during fermentation

The $\mathrm{NaCl}$ of the brine samples should be considered very high but suggested by industrial applications as the only effective means of conservation the product. Concerning the final salt concentration in olive flesh, values of $7.4 \%$ for Edincik and $6.9 \%$ for Gemlik were attained at the end of the 225th day of fermentation.

Acidity and $\mathrm{pH}$ values greatly affect the establishment and extent of the growth of microorganisms and therefore the progress of the fermentation. Degree of fruit ripeness and initial salt concentration of brine are important factors that control the $\mathrm{pH}$ value. When the olives are ripe, the $\mathrm{pH}$ value is much more dependent on the salt concentration. For example, placement of ripe olives in low $\mathrm{NaCl}$ level $(2 \%)$ leads to a rapid drop in $\mathrm{pH}$, but if the salt level is high $(9 \%)$ the $\mathrm{pH}$ value in the brine of ripe olives does not reveal any differences from that of less ripe olives (8). In spontaneous fermentation $\mathrm{pH}$ should be maintained at 4-4.5 to prevent the development of spoiling bacteria. In the traditional method used, the initial $\mathrm{pH}$ values of brine were approximately 6 in both varieties, then they stabilized between the values of 4.2 and 4.4 after the 100 days for Edincik and between the values of 4.9 and 5.2 after the 150 days' fermentation for Gemlik variety (Figure 2). The absence or very limited growth of lactic acid bacteria do not allow a rapid decrease in $\mathrm{pH}$, however, high salt concentration prevents the growth of undesirable microflora.

As Figure 3 indicates, the formation of acid began very soon after brining, continued at a rapid rate and reached at 


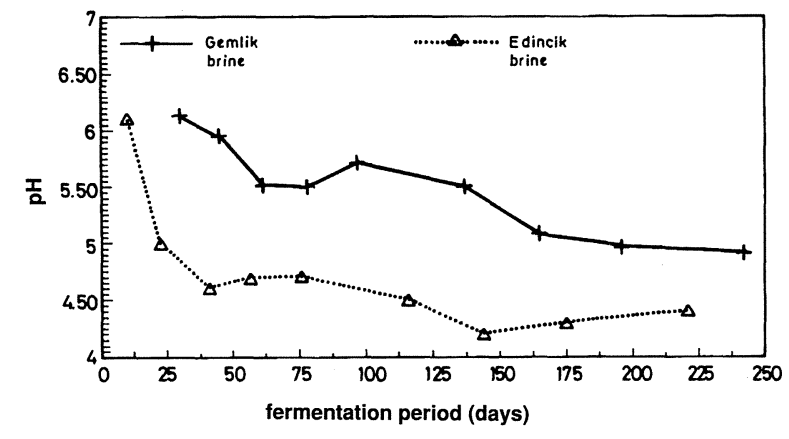

Fig. 2

Changes in $\mathrm{pH}$ values in brine during fermentation

the final values of $0.41 \%$ (as lactic acid, w/v) for Edincik and $0.35 \%$ for Gemlik. The formation of acid coincides with the corresponding $\mathrm{pH}$ changes. However, the differences between $\mathrm{pH}$ values were not reflected to the free acidity content from a pronounced manner in two varieties probably because of the different buffering capacities of olive varieties which depends on organic acids formed and the existing inorganic substances (10) (15).

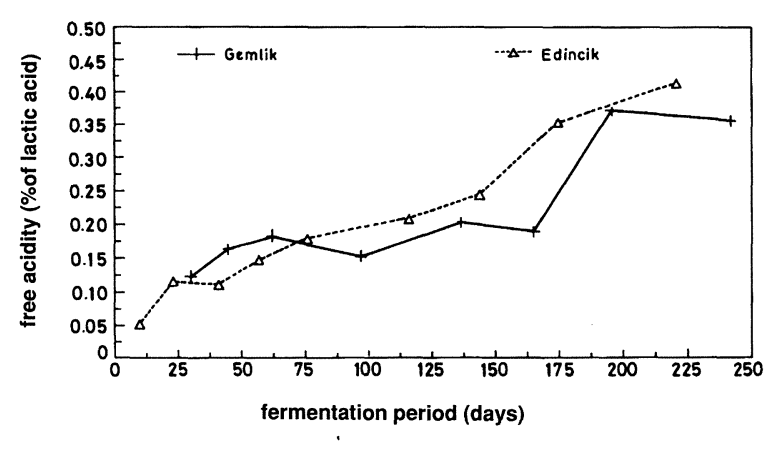

Fig. 3

Changes in free acidity in brine during fermentation

In olive fermentation, special attention should be paid on the original sugar content of the fruit and its evolution in brine being fundamental component which effectively controls the fermentation. When the sugar concentration is low in brine, fermentation proceeds slowly even under ideal conditions because of the resistant skin of olive. The availability of fermentable material depends on the following conditions (10) (13) such as the ratio of olive/brine, diffusion rate of soluble sugar to brine depending on the permeability of the skin, temperature and salt concentration and finally development and composition of the microflora. In current study, it was found that, the concentration of sugar in the brine increased rapidly, then decreased and finally fell to low levels $(0.98 \%$ for Edincik and $0.65 \%$ for Gemlik olives). The decreasement in brine-sugar concentration depends on the activity and the variety of microorganisms.

The higher sugar content of Edincik variety resulted in more rapid decreasement in $\mathrm{pH}$ due to the yeast fermentation probably by their vigorous utilization of the sugars and the production of acetic acid and $\mathrm{CO}_{2}$. The main problem encountered by olive processors is that, the completion of fermentation was succeeded seldomly. So that, conservation brine of the final product with high residual reducing sugar values above 0.4-0.6 g/100 ml exposes to undesired microbial growth and causes marketing problems $(8,10)$. As it can be seen in Figure 4, reducing sugar was leached into brine more rapidly in the variety of Edincik than the Gemlik variety until the 75th day of fermentation. At the end of the 225th day, Edincik variety has completed the fermentation with the reducing sugar value of $0.65 \%$ in flesh. In Gemlik variety, fermentation was prolonged and the final reducing sugar value was still $1.8 \%$ on the 237 th day of fermentation.

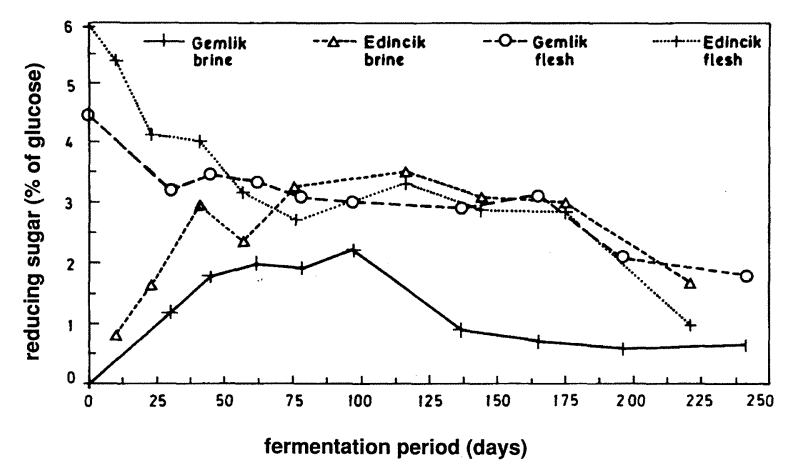

Fig. 4

Changes in reducing sugar content during fermentation

In another research conducted on olive fermentation by Çetin and Pamir (12) in drums of 40 I capacity and with $10 \%$ salt concentration realized with the same olive varieties. It was found that, reducing sugar quantites in brine in both varieties were approximately $1 \%$ at the end of the 230 th day of fermentation. Nonetheless, an important factor, the ratio of olive/brine was not mentioned to make any comparison.

Olives processed by traditional method generally contain certain quantity of bitterness which characterizes the final product. Phenolic compounds present in olives, being responsible from the bitterness, also have the major inhibitory effect on microorganisms which known to limit the complex fermentation. In order to improve the fermentation of olives, an increasing knowledge about the role of phenolic compounds in the fermentative process is necessary (16). Lactic acid bacteria naturally present on the surface of the olives are among the most effected microorganisms from phenolic glucosides, oleuropein. On the other hand the high tolerance of yeasts to oleuropein is reported by many researchers (15). Diffusion of phenolic compounds to the brine is closely related to the permeability of the olive skin. After placing the olives in brine, phenolic compounds began to increase in brine in two months and then reached at the value of $1 \%$ for each olive variety on the 240th day of fermentation. At the end of fermentation the polyphenol quantity in flesh was reduced $(1.25 \%$ in flesh) nearly to the 
half of the original value of the raw olive material. Polyphenols in Edincik olive flesh were leached into the brine more rapidly than Gemlik variety, like other soluble components (Figure 5).

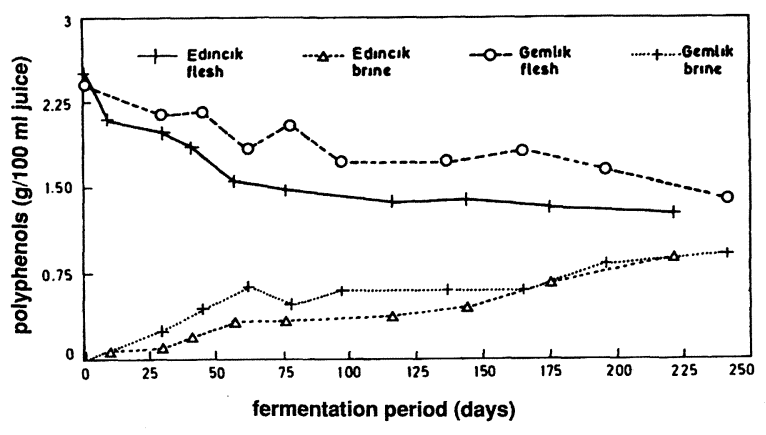

Fig. 5

Changes in the polyphenol content during fermentation

Changes in some other components such as moisture, ash and protein have also been followed during fermentation (Table III and IV). The ash contents have increased due to the penetration of salt from brine into olive in Gemlik and Edincik varieties reaching at the values of $6.63 \%$ and to $5.63 \%(\mathrm{w} / \mathrm{w})$, respectively. In Edincik variety the moisture loss $(56.75 \%$, on the 41 st day of the fermentation) has been greater than that of Gemlik, then, the moisture content increased to a maximum value of $60.92 \%$ between the 57 th and the 116th days and decreased toward the end of the fermentation (58.17\%). In Gemlik variety, after a decrease $(42.19 \%)$ within 62 days, the moisture content has increased until the end of the fermentation (46.60\%). In both varieties the contents of protein have slightly increased to $1.30 \%$ and $1.86 \%$ in Gemlik and Edincik varieties, respectively.

Table III

Changes in some chemical components in Edincik variety during fermentation

\begin{tabular}{cccc}
\hline Fermentation period (days) & Moisture \% & Ash \% & Protein \% \\
\hline 10 & 56.09 & 3.48 & 1.17 \\
23 & 56.41 & 4.69 & 1.24 \\
41 & 56.75 & 5.18 & 1.47 \\
57 & 59.63 & 6.13 & 1.09 \\
76 & 58.07 & 5.87 & 1.17 \\
116 & 60.92 & 5.30 & 1.14 \\
144 & 53.74 & 5.38 & 1.28 \\
175 & 58.17 & 5.63 & 1.30 \\
\hline
\end{tabular}

Regarding the development of microorganisms during fermentation, sporulated Gram-negative, coliform and lactic acid bacteria growth were not detected. However, $52 \times 10^{3}$ $\mathrm{cfu} / \mathrm{g}$ Pediococcus sp. was found in Edincik olives only between the 76th and the 89th days of fermentation.

Yeast population, responsible for the fermentation and being resistant to the bitterness was developed starting from the 40th day of brining in both varieties and existed all along the fermentation (Figure 6). Interestingly, degradation of oleuropein by a yeast strain is demonstrated by an Italian researcher (17).

Table IV

Changes in some chemical components in Gemlik variety during fermentation

\begin{tabular}{cccc}
\hline Fermentation period (days) & Moisture \% & Ash \% & Protein \% \\
\hline 30 & 42.00 & 4.35 & 2.01 \\
45 & 42.08 & 4.92 & 1.93 \\
62 & 42.19 & 5.13 & 1.98 \\
78 & 46.03 & 6.14 & 1.83 \\
97 & 44.08 & 5.93 & 1.75 \\
137 & 45.28 & 6.08 & 1.64 \\
165 & 44.66 & 5.90 & 1.86 \\
196 & 46.60 & 6.63 & 1.86 \\
\hline
\end{tabular}

The composition of the yeast flora was consisted of Debaryomyces hansenii, Rhodotorula mucilaginosa, $R h$. glutinis, Candida membranifaciens and Saccharomyces cerevisiae for Edincik.

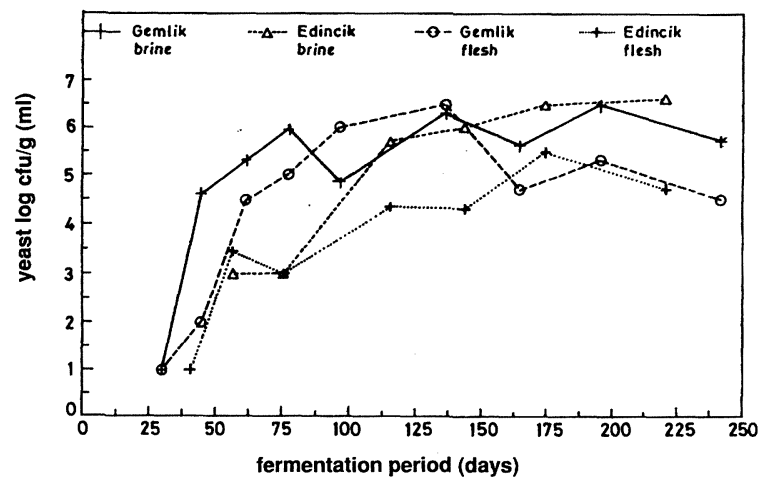

Fig. 6

Evolution of yeast population during fermentation.

One of the main problems in natural black olive processing is the formation of gas-pockets (fish-eyes) in olive flesh caused by the accumulation of gas inside. The so called "alambrado" in Spanish, renders the product completely worthless (8). According to our observations, after 180 days' brining, occurrence of fish-eyes were detected in both of the olive varieties. This abnormality can be originated from either metabolic changes occurred in olive or dominating microflora of yeasts. In this regard, the yeast strains which can cause this defect rests to be examined in these two olive varieties. To solve similar problems encountered in spanish olives, intensive studies were undertaken at the Institute of Fat and Its Derivates, Sevilla, and an aerobic fermentation process succesfully applied in black olive fermentation (18). It was also demonstrated that the most representative yeast flora was mainly consisted of Saccharomyces oleaginosus and Hansenula anomala produced 
the most elevated proportion of alambrado in Spanish olive varieties (10).

\section{CONCLUSION}

Comparison was realized between the two varieties of olive for their suitability in black olive fermentation. As a result, the variety of Edincik has completed fermentation in comparable short period (220-225 days) than Gemlik variety due to the rapid leaching of soluble components into the brine, specially the reducing sugars and polyphenols. After brining, salt concentration, has reached at an equilibrium more rapidly with a more rapid moisture loss and a lower salt concentration in brine, for Edincik variety. According to sensory evaluations, the final product proved better characteristics of color, texture and taste.

In general, it can be concluded that $\mathrm{NaCl}$ content of brine is very high since it should be $8 \%$ according to international standards. Nonetheless, it is essential in traditional technology to preserve the product. Furthermore, it greatly affects the types and the number of microorganisms orienting the fermentation and giving the characteristics to the final products. As a result, olives are salty, and therefore characteristic fruit aroma is usually masked with salty taste. Thus, modification and development of existing technology are necessary. For this purpose, various attemps have been made in Turkey. For instance, application of aerated system to accelerate the fermentation period as well as eliminating "alambrado" defects has been realized and satisfactory results were obtained (20). Replacement of the $\mathrm{pH}$ controlled brine at appropriate steps and application of alkaline treatment will yield desired products. Furthermore, the use of starter cultures orienting the fermentation in black olive will result in standardized high quality olives. Taking this fact into account, our studies on the use of starter cultures in olive fermentation have been initiated and being continued progressively.

\section{ACKNOWLEDGEMENT}

This work was financially supported by NATO-SFS Programme under the scope of the NATO-TU-FERMENTECH Project. We would like to thank to Prof. M. PALA, Head of Department of Food Technology and Refrigeration, for supporting the project studies, to General Directory of MARMARABIRLIK, Union of the Olive Producers Cooperatives, for their collaboration, to Miss. E. GÖZÜM and Mr. B. ÇIRAK for their technical assistance in laboratory studies.

\section{REFERENCES}

1. IOOC-COI (1988).-«What is the International Olive Oil Council».-IOOC Document p.1-8.

2. Harrigan, W.F. and McCance, M.E. (1976).-«Laboratory methods in food and dairy microbiology".-452 p.-Academic Press. London.

3. Vanos, V. and Cox, L. (1986).-«Rapid routine method for the detection of lactic acid bacteria among competitive flora".-Food Microbiol. 3, 223234.

4. MERCK (1987).-«Culture media handbook»--Darmstadt $232 \mathrm{p}$.

5. Collins, C.H. and Lyne, P.M. (1987).-«Microbiological methods».-450 p.Butterworth Co. Publishers Ltd., London.

6. Vand der Walt, J.P. and Yarrow, D. (1984).-«Methods for the isolation, maintenance, classification and identification of yeasts" en The yeasts, a taxonomic study p. 45-104.-N.J.W. Kreger-Van Rij (Ed.).-Elsevier Science Publishers. B.V. Amsterdam. The Netherlands.

7. Barnett, J.A.; Payne, R.W. and Yarrow, D (1990).-«Yeasts: characteristics and identification» 1002 p.-Cambridge University Press, Cambridge. England.

8. IOOC (1990).-«Table olive processing» 109 p.-International Olive Oil Council. Madrid.

9. AOAC (1984).-«Invert sugar layne-eynon, general volumetric method».31.034 AOAC, Arlington. Virginia. USA.-p. 579.

10. Fernández Díez, M.J.; Ramos, R.C.; Garrido Fernández, A.; Cancho, F.G.; Pellisó, F.G.; Vega, M.N.; Moreno, A.H.; Mosquera, I.M.; Navarro, L.R.; Durán Quintana, M.C.; Roldán, F.S.; García, P.G.; Gómez-Millán, A.C. (1985).-«Biotecnología de la aceituna de mesa» 475 p.-Servicio de Publicaciones del C.S.I.C. Madrid.

11. Fernández Díez, M.J. (1983).-«Olives» en Biotechnology. Vol. 5 p. 380397.-H.J. Rehm and G. Redd (Eds.).-Verlag Chemie. Weinheim.

12. Çetin, H.H. and Pamir, M.H. (1980).-«Experiments on the effect of oleu ropein on the lactic acid fermentation of black olives» p. 403.-University of Ankara. Faculty of Agriculture.

13. Cancho, G.F.; Vega, M.N.; Durán Quintana, M.C.; Garrido Fernández, A. (1975).-«El proceso de fermentación en las aceitunas negras maduras en salmuera".-Grasas y Aceites 26, 297-309.

14. Fleming, H.P. (1982).-«Fermented vegetables» en Economic microbiology. Fermented food. Vol. 7 p. 227-258.-A.H. Rose (Ed.).-Academic Press. London.

15. Balatsouras, G.; Tsibri, A.; Dalles, T. and Doutsias, G. (1983).-«Effects of fermentation and its control on the sensory characteristics of conservolea variety green olives».-Appl. Environ. Microbiol. 46, 68-74.

16. Ruiz-Barba, J.L.; Fernández, A.G. and Díaz, R.J. (1991).-«Bactericidal action of oleuropein extracted from green olives against lactobacillus plantarum".-Lett. Appl. Microbiol. 12, 65-68.

17. Pelagatti, O. (1983).-«L'impiego di lieviti oleuropeinolitici nella preparazione della olive da tavola nere».-Ann. Ist. Sper. Elaiotecnica 9, 3-10.

18. García Garcia, P.; Durán Quintana, M.C. y Garrido Fernández, A. (1982).-«Modificaciones del proceso de fermentación de aceitunas negras al natural para evitar alteraciones".-Grasas y Aceites 33, 9-17.

19. Fernández Díez, M.J. (1984).-«Changes in the chemical components during the processing of table olives and their relation to the quality" en Proceedings M.O.C.C.A. Vol. 1 p. 301-308.

20. Özay, G.; Borcakli, M.; Alperden, I.; Özsan, E. and Erdek, Y. (1991).«Examination of the fermentation of black olives processed with classical and aerated systems" p. 296-310.-Proceedings of the Bursa II. International Food Symposium, 1-3 October, 1991. Bursa. Turkey.

(Recibido: Diciembre 1992) 